\title{
Responding to crisis and building forward better: The relevance of curriculum
}

\author{
Yao Ydo ${ }^{1}$
}

Accepted: 27 August 2021 / Published online: 24 September 2021

(C) UNESCO IBE 2021

The Covid-19 pandemic has brought into focus many of the vulnerabilities of our educational systems. Among other issues, it cast light on the challenges of teaching and learning, as students and teachers wrestled with the technological logistics of an exceptional event that triggered the world's biggest educational technology (edtech) implementation in history almost overnight (Gual Soler and Dadlani 2020).

Not only did the Covid-19 pandemic heighten the urgency to address the digital divide and unequal access to quality education, but it also revealed huge fissures in the way curricula responded to the crisis. The structural incapacity of curriculum to respond promptly and efficiently to the pandemic offers us the opportunity and the necessity to unravel bedrock assumptions and stimulates further discussion about the nature of curriculum. By analyzing what we have learned from this crisis and the kind of reality it has forced us to confront, we can imagine curricula capable of making sense of the complex forces driving transformational change across economies, industries, and global issues.

Are our educational systems preparing students for a world driven by sudden, unforeseen, and disruptive change? What does it take to change mindsets? Can we imagine curricula that have the capacity to stay proactive and contribute to the prevention/management of external vulnerabilities, including outbreaks and emergencies; Industry 4.0; social, economic, and political changes (e.g., economic inequality; social distancing; the emergence of right-wing, even authoritarian, leaders in democratic societies); climate change, and demographic events (e.g., the refugee crisis, immigration, and aging populations)? And how do we bring about "building forward better", without losing our groundings and bearings?

I am very pleased to introduce this triple special issue of Prospects, which addresses these questions head on, by foregrounding the work of more than sixty leading curriculum researchers. Their contributions, guided by the prominent curriculum theorist William F. Pinar, illuminate, magnify, and discover anew the importance of curriculum preparedness

Yao Ydo

ibe.prospects@unesco.org

1 UNESCO International Bureau of Education, P.O. Box 199, 1211 Geneva 20, Switzerland 
and response, through probing analyses of research, policy, and practice, as well as through using the concept of curriculum as "a bridge between the social and subjective in a relationship between public and private" (Pacheco 2009, p. 49). Thus, curriculum is "a conversation, better said, a complicated conversation that transforms the personal into curriculum subject" (p. 50).

Professor Pinar uses the full weight of his extensive knowledge in education research, teaching, policy, and action to argue that the Covid-19 crisis is a curriculum crisis, because it is a humanitarian crisis: "Survival—physical, psychological, educational—is at stake". In order to reconstruct quality education, we must begin by improving its foundation, whereby "the student-the individual person-should remain central to any conception of curriculum, to any organization of pedagogical communication, indeed to the very project of education itself" (Pinar, in this volume). The result is a seasoned and superbly articulated examination of the principles and practices of curriculum and its teaching and learning during crisis, while casting an ever-vigilant eye on a fundamental question in the post-Covid-19 era: "What knowledge is of most worth when constructing a new social and global awareness through curriculum?" (Sümer Aktan, in this volume).

Innovative, cultured, and consistently captivating, this special issue is bold and, in the field of comparative and international education, unprecedented.

\section{References}

Gual Soler, M., \& Dadlani, K. (2020, August 13). Resetting the way we teach science is vital for all our futures. World Economic Forum. https://www.weforum.org/agenda/2020/08/science-education-resetstem-technology/

Pacheco, J. A. (2009). Pinar's curriculum theorizing. In J. A. Pachedo (Ed.), Whole, bright, deep with understanding: Life story and politics of curriculum studies. In-between William Pinar and Ivor Goodson (pp. 49-72). Leiden: Brill.

Publisher's Note Springer Nature remains neutral with regard to jurisdictional claims in published maps and institutional affiliations. 